\title{
Oil pollution and Baltic mysids: acute and chronic effects of the water soluble fractions of light fuel oil on the mysid shrimp Neomysis integer
}

\author{
Roy Laughlin* and Olof Lindén \\ Swedish Environmental Research Institute (IVL), Baltic Sea Laboratory, Utovagen, Karlskrona, Sweden
}

\begin{abstract}
Mysid shrimp, Neomysis integer, were acclimated to 4 temperatures $\left(6,10,15\right.$ or $\left.20^{\circ} \mathrm{C}\right)$ and exposed to water-soluble fractions (WSF) of light fuel oil under 2 different regimes. The first, a chronic exposure scheme, employed $\mathrm{ng} \mathrm{l}^{-1}$ hydrocarbon levels and lasted $2 \mathrm{wk}$. The second, acute exposure, employed $\mu \mathrm{g} \mathrm{l}^{-1}$ levels and exposure occurred during determination of physiological parameters. We determined oxygen consumption, ammonium excretion rates, and computed oxygen nitrogen $(O: N)$ ratios. Oxygen consumption was more strongly influenced by temperature than was ammonia excretion. Chronic exposure for $2 \mathrm{wk}$ to aromatic petroleum hydrocarbons at the $\mathrm{ng} \mathrm{l}^{-1}$ level did not significantly affect the parameters measured. Exposure to WSF at concentrations between ca. 200 and $1000 \mu \mathrm{g} \mathrm{l}^{-1}$ produced increases in oxygen consumption and decreases in ammonia excretion; these were strongly influenced by temperature with the greatest effect of oil exposure occurring at $21.5^{\circ} \mathrm{C}$, the highest temperature tested. Laboratory rearing conditions were shown to increase oxygen consumption and ammonia excretion rates compared to those of field-collected mysids; however, the relative response to oil was not affected.
\end{abstract}

On February 19, 1981, the tanker 'Sefir' sank in the Baltic Sea in $50 \mathrm{~m}$ of water, approximately $10 \mathrm{~km} \mathrm{SE}$ of the Swedish island of Oland. The cargo consisted of approximately 800 tons of No. 0 and No. 1 fuel oil. At first, leakage from the ship on the bottom appeared to be slow but later the quantities increased. When the oil surfaced, it drifted, driven by winds and surface currents and parts of it landed on the southeast coast of Oland. Extensive mortality of littoral fauna was observed where the oil came ashore (Lindén et al., 1983). When the vessel was raised in late April it was found that about half of the cargo had leaked out.

The present studies were initiated to address several aspects of oil pollution in the Baltic Sea. We determined the acute effect on oxygen uptake and ammonia excretion of the common Baltic mysid Neomysis integer following short-term exposure to $\mu \mathrm{g} \mathrm{l}^{-1}$ levels of water-soluble fractions (WSF) of this light oil. In addition, the effects on oxygen consumption and

\footnotetext{
- Present address: University of California, Naval Biosciences Laboratory, Naval Supply Center, Bldg 844, Oakland, California 94625, USA
}

ammonia excretion were determined for $\mathrm{ng} \mathrm{l}^{-1}$ exposure levels at 5 -d intervals for a period of $15 \mathrm{~d}$. The experimental protocol incorporated tests for both the acute and chronic tests over a temperature range between 6 and $20^{\circ} \mathrm{C}$. With the exception of lowest (winter) temperatures, these span the environmental range for the species. Thus by considering the effect of temperature, a dominant physical factor of the environment, the predictive model generated from the statistical analysis hopefully has been strengthened.

\section{MATERIALS AND METHODS}

Collection and maintenance of mysids: Adult Neomysis integer were collected with a dipnet at Stendörren, about $80 \mathrm{~km}$ south of Stockholm. Several collections were made in August and September (1981) as noted in the text. The catch consisted of late juveniles, males, non-ovigerous and ovigerous females. In the lab, mysids were fed Tetramin ${ }^{(R)}$ fish food twice daily. Between 500 and 1000 mysids were kept in 70 to 801 of flowing Baltic Sea water taken from a depth of $40 \mathrm{~m}$. 


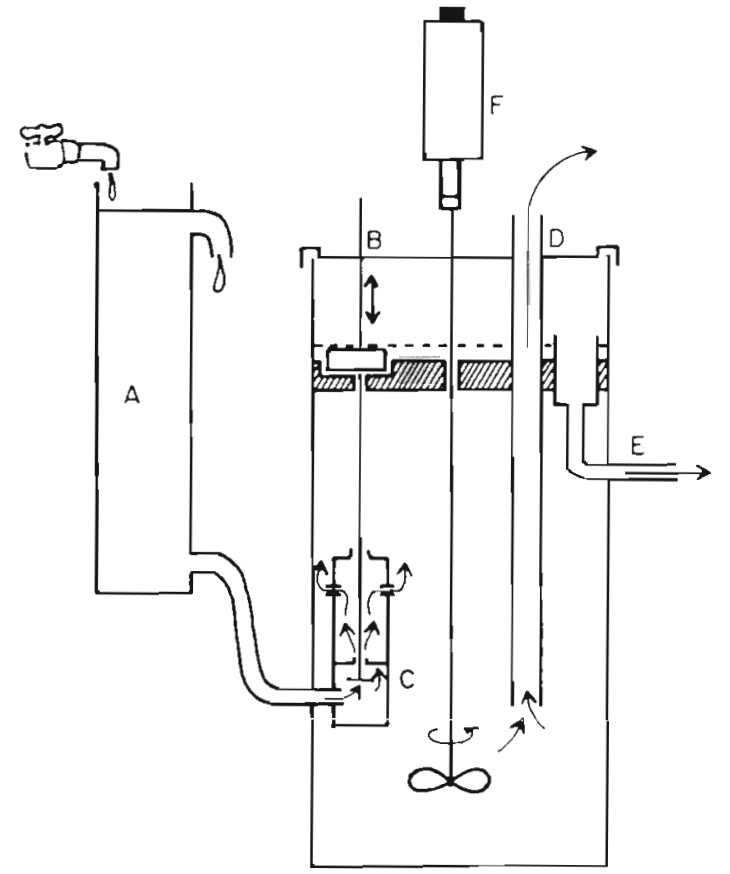

Fig. 1. Schematic diagram of the water-soluble fraction maker. The stirring motor was set at low speed to avoid dispersing oil in the water. A flotation valve kept the water level constant as the WSF were withdrawn by dosing pumps. (A) Water reservoir with overflow; (B) float; (C) valve connected to float; (D) outlet for dosing pumps; (E) used oil evacuation pipe; (F) electric stirrer

Chronic oil exposure: During chronic exposure, factorial combinations of 4 temperatures and 2 oil doses (control or exposed) were used. Two 80-1 aquaria were put into each of 4 large water baths adjusted to a temperature of $6,10,15$ or $20^{\circ} \mathrm{C}$. These temperature regimens were generally stable throughout the course of a day but did occasionally vary $\pm 1.5 \mathrm{C}^{\circ}$ during warmer or cooler periods as the weather changed.

The solution of water-soluble fractions used for all tanks were made in one mixer schematically shown in Fig. 1. Four dosing pumps withdrew water from this tank to dose the oil-exposed group at each temperature. These pumps delivered WSF solutions at a rate of about $900 \mathrm{ml} \mathrm{h}^{-1} \tan \mathrm{k}^{-1}$. According to the nomograms in Sprague (1969), the half-time for water turnover in the tank would be ca. $2.5 \mathrm{~d}$. In the control tanks, similar (but not identical) amounts of uncontaminated water were added. Especially at the higher temperatures, these flow rates would have been insufficient to provide oxygen to the number of mysids present. Therefore, aeration was supplied to all tanks. Aeration is no doubt a primary factor for the low aromatic hydrocarbon concentrations present in the oil exposure tanks (see below).

All mysids used in the chronic tests were from a single collection (August 8,1981 ) when field water temperatures were 14 to $15^{\circ} \mathrm{C}$. In the lab, the mysids were put directly into the various exposure conditions without temperature acclimation. This treatment appeared to cause no acute temperature shock. Mysids began eating Tetramin ${ }^{(R)}$ the day following capture.

Acute oil exposure: For the acute exposure regime, WSF stock solution was prepared following the method of Anderson et al. (1974a) using $7 \%$ o s water at $15^{\circ} \mathrm{C}$. Subsequently, the water phase was withdrawn and brought to the test temperature. Dilutions to provide the exposure solutions were made just prior to use in the respirometers.

Mysids used for the acute tests were collected at several different times and temperature-acclimated for periods of not less than $5 \mathrm{~d}$. Those exposed to 18 and $21.5^{\circ} \mathrm{C}$ were acclimated for the shortest period of time due to long-term deleterious effects of this high temperature.

For a corollary experiment, field-collected mysids were tested under acute exposure conditions. These animals were collected $2 \mathrm{~h}$ before use in respirometry. They were not fed in the lab and all other manipulations prior to respirometry were minimized to avoid 'handling effects'.

Hydrocarbon analysis: A limited number of hydrocarbon analyses were performed to characterize exposure regimes. During the chronic exposure tests, flow-through solvent extractors containing carbon tetrachloride were used during a 3 -d period on several tanks. During the acute tests, 100 to $200 \mathrm{ml}$ aliquots of the $100 \%$ WSF mixture were extracted with hexane for analysis of petroleum hydrocarbons. Several different analytical procedures were used to estimate hydrocarbon levels: infrared spectrophotometry (API, 1958), ultraviolet spectrophotometry (Neff and Anderson, 1975) or quantitative gas chromatography (Rudling, 1976).

Respirometry and ammonia determinations: Oxygen partial pressures were determined using the oxygen electrode in a Lexington Instruments blood gas analyzer (Laughlin et al., 1979). Ammonia, determined by measuring $\mathrm{NH}_{4}{ }^{+}$levels in the medium, was measured using the phenol-hypochlorite method (Solorzano, 1969). Flasks or large test tubes served as respirometry chambers, depending on the temperature. Use of smaller containers in the lower temperatures, where oxygen consumption was lower, insured approximately equal changes in oxygen partial pressures during respirometry. Under the protocols used here, partial pressures did not drop below half air saturation. In all tests respirometry periods were from 16 to $22 \mathrm{~h}$, continuing overnight.

Mysids exposed to chronic low levels initially were tested in pairs in the respirometers. However, at $20^{\circ} \mathrm{C}$ mortality was common for one or both members of the 
pair. Initially, we attributed this to cannibalism and the number of mysids was subsequently reduced to 1 flask $^{-1}$. This step did not alleviate mortality. We believe that this mortality was, in fact, attributable to unsuccessful attempts to molt. Ecdysis is a period of high vulnerability for crustaceans under any circumstances and we suspect that at $20^{\circ} \mathrm{C}$, a relatively high temperature, it was impossible for the mysids to accrue enough metabolic reserves to sustain themselves during the process. In general, 6 replicates per factor combination were prepared but these often were reduced owing to mortality, molting or release of larvae. Water uncontaminated by WSF was used in the respirometers. Flasks containing water but no mysids had negligible decreases in oxygen concentration or ammonia production.

For acute exposure, 10 replicates per factor combination was the rule, but once again reductions in this number were necessary because of juvenile release, molting or deaths in some tests, especially at the higher temperatures. These problems led to rejection of the data for that replicate.

Statistical analysis: Data were analyzed using either the ANOVA or REGRESSION subroutines in SPSS (Nie et al., 1975). For the analysis of variance, a regression approach was used. A full cubic model of all cubic, quadratic, linear and linear interaction terms was analyzed using a stepwise procedure. Terms were entered and tested for a significant increase in the fit of the model. The final regression equation was plotted using response surface analysis techniques. Unless otherwise noted, weight of the mysid was treated as a covariate, because many physiological functions display weight-dependent patterns, i.e. oxygen consumption (Hemmingsen, 1960). In a separate set of experiments, not reported here, weight dependence of oxygen consumption, ammonia excretion, and oxygen: nitrogen ratios were measured over a size range of adult mysids and the data fitted to a power function:

$$
\mathrm{R}=\mathrm{a} \mathrm{W}^{\mathrm{b}}
$$

where $\mathrm{R}=$ rate of physiological function; $\mathrm{W}=$ weight of the animal. The correlations found were small or non-existent, probably due to the relatively narrow weight range tested. Nevertheless, it did seem reasonable to treat weight consistently as a covariate in an attempt to account for as much of the variance as possible.

\section{RESULTS}

\section{Hydrocarbon concentrations}

The water soluble components of this oil were primarily mono- and dicyclic aromatic components (Fig. 2). Monoaromatics, probably alkyl-substituted

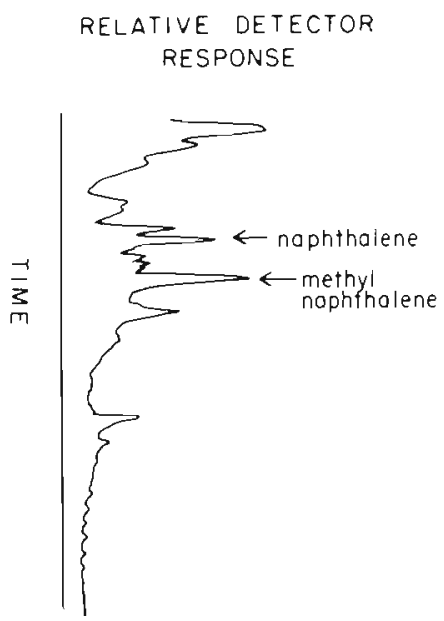

Fig. 2. Gas chromatogram of hexane extracts of water-soluble fractions of 'Sefir' oil. WSF is dominated by mono- and diaromatic hydrocarbons and their alkyl-substituted isomers

benzene, were predominant; naphthene and its alkylsubstituted isomers were also prominent. The undiluted WSF used for the acute tests had total aromatic hydrocarbon concentrations between 2.4 and $5.1 \mathrm{mg}$ $1^{-1}$ (Table 1 ). The variation was random with respect to the test temperatures and does not reflect differences caused by physical factors since these were nearly identical. Precise determinations of the concentrations of WSF in the chronic tests were not successful because detritus in the tanks tended to clog siphon lines and render volume estimates of sampled water unreliable. Given the probable errors consequently introduced, we estimate that the mysids in the tanks were exposed to between 200 and $500 \mathrm{ng} \mathrm{l^{-1 }}$. Temperature exerted no obvious effect on hydrocarbon concentration.

\section{Chronic exposure}

Both oxygen uptake and ammonia excretion rates are highly temperature dependent over the range

Table 1. Concentration of aromatic hydrocarbons in $100 \%$ WSF used in acute exposures. Values given denote total aromatic hydrocarbon $\left(\mathrm{mg}^{-1} \mathrm{l}^{-1}\right)$ content as estimated by gasliquid chromatography. The second $15^{\circ} \mathrm{C}$ value is that for the group of 'wild mysids' (see Fig. 14)

\begin{tabular}{|cc|}
\hline $\begin{array}{c}\text { Test temperature } \\
\left({ }^{\circ} \mathrm{C}\right)\end{array}$ & $\begin{array}{c}\text { Aromatic hydrocarbon } \\
\text { concentration } \\
\left(\mathrm{mg} \mathrm{l}^{-1}\right)\end{array}$ \\
\hline $6^{\circ}$ & 2.4 \\
$10^{\circ}$ & 2.4 \\
$15^{\circ}$ & 3.3 \\
$18^{\circ}$ & 5.1 \\
$25^{\circ}$ & 4.6 \\
$15^{\circ}$ & 4.0 \\
\hline
\end{tabular}



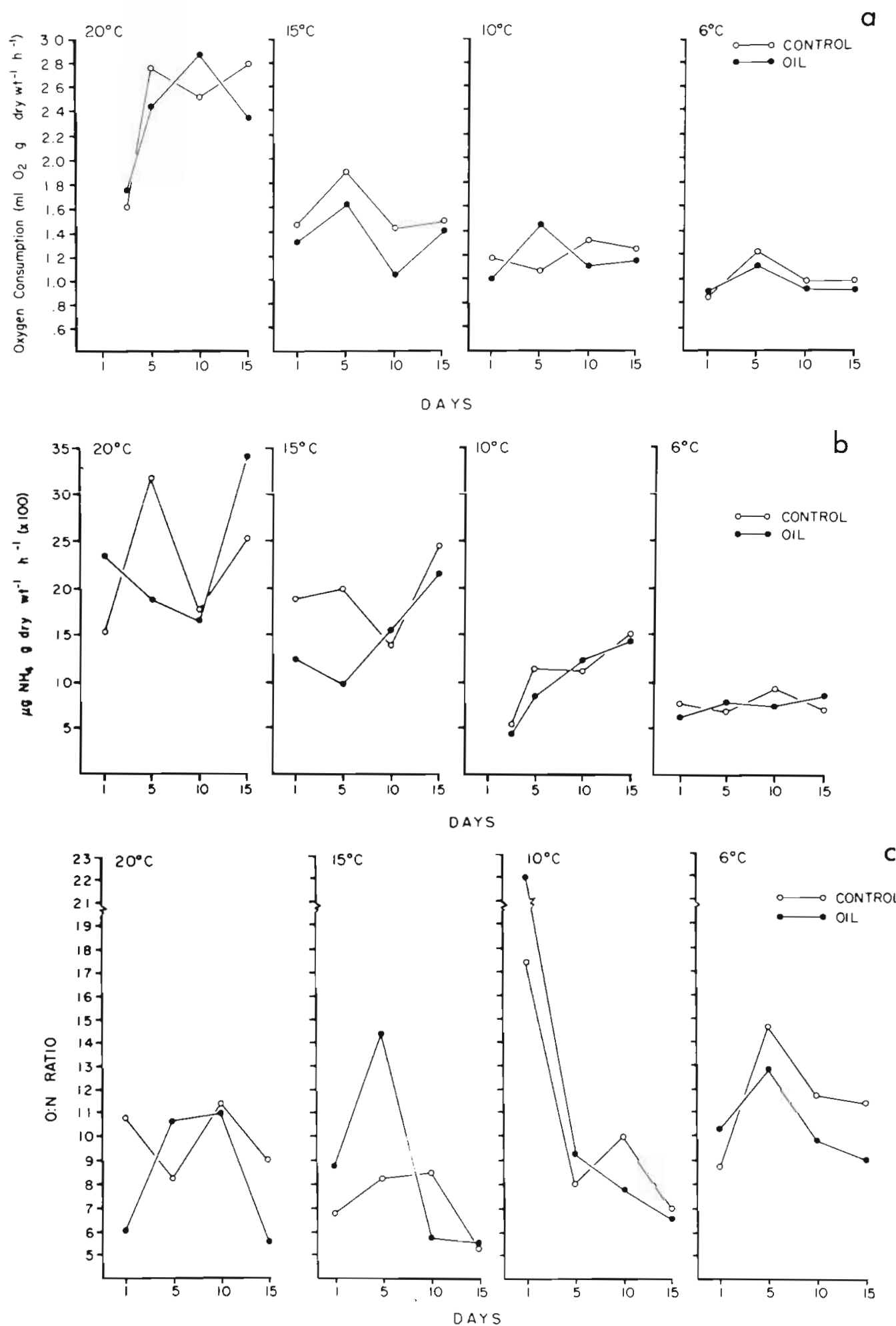

Fig. 3. Neomysis integer. (a) Oxygen consumption rates; (b) ammonia excretion rates; (c) oxygen : nitrogen ratios of adult mysids chronically exposed to WSF of light fuel oil at 4 different temperatures

tested, with respiration rates showing the most marked effects (Fig. 3). On the first day of testing, oxygen consumption values at $20{ }^{\circ} \mathrm{C}$ were between 1.6 and 1.8 $m g \mathrm{O}_{2} \mathrm{~g}^{-1}$ dry weight $\mathrm{h}^{-1}$. By the fifth day, they had risen to between 2.4 and $2.8 \mathrm{mg} \mathrm{O}_{2} \mathrm{~g}^{-1}$ dry weight $\mathrm{h}^{-1}$ and tended to remain at these high rates for the dura- 
tion of the experiment. At $15^{\circ} \mathrm{C}$, respiration rates for both control and oil-exposed groups were between 1.3 and $1.6 \mathrm{mg} \mathrm{O}_{2} \mathrm{~g}^{-1}$ dry weight $\mathrm{h}^{-1}$. In $10^{\circ} \mathrm{C}$, the rates were between 1.0 and $1.3 \mathrm{mg} \mathrm{O}_{2} \mathrm{~g}^{-1}$ dry weight $\mathrm{h}^{-1}$ on all the days tested, while those for $6{ }^{\circ} \mathrm{C}$ were between 0.8 and $1.0 \mathrm{mg} \mathrm{O}_{2} \mathrm{~g}^{-1}$ dry weight $\mathrm{h}^{-1}$. Smaller $\mathrm{Q}_{10}$ 's were observed at lower temperatures. Although $Q_{10}$ 's did vary with the day of the test, usually they were between 1.5 and 2.0, indicating a significant degree of temperature compensation over the range from 6 to $15^{\circ} \mathrm{C}$.

The effects of oil on the respiration rates exhibited 2 trends, dependent on the day and temperature, which may not at first appear consistent. In 6 and $15^{\circ} \mathrm{C}$, control respiration rates were always slightly above that of the oil-exposed group at that temperature. Except for Day 5, the group at $10^{\circ} \mathrm{C}$ followed similar trends. (The group on Day 5 may show anomalous behavior, perhaps because of undetected molting or reproductive behavior). The trends at $20^{\circ} \mathrm{C}$ were not consistent at all with respect to oil exposure, probably a reflection of the major stress a temperature of $20^{\circ} \mathrm{C}$ can produce acting alone.
Analysis of variance was performed using weight and days as covariates and temperature and oil as factors. The results are shown in Table $2 \mathrm{a}$. Weight was the only significant covariate $(F=6.048 ; p=0.015)$ and temperature the only significant factor $(\mathrm{F}=22.431 ; \quad \mathrm{p}=0.001) . \quad \mathrm{Oil}, \quad$ and the interaction between oil and temperature, were not statistically significant.

Ammonia excretion rates are strongly influenced by temperature (Fig. 4), but not as consistently or strongly as oxygen consumption. Mean rates of the different groups increased with temperature. At $6{ }^{\circ} \mathrm{C}$, they were between 5 and $10 \times 10^{-8} \mathrm{gm} \mathrm{NH}_{4}^{+} \mathrm{g}^{-1}$ dry weight $\mathrm{h}^{-1}$. Initially, those at $10^{\circ} \mathrm{C}$ were within this same range but then increased to final values near $15 \times 10^{-8} \mathrm{gm}$ $\mathrm{NH}_{4}{ }^{+} \mathrm{g}^{-1}$ dry weight hc ${ }^{1}$. At both $15^{\circ}$ and $20^{\circ} \mathrm{C}$, the values fluctuated widely; in general, they were between 15 and $25 \times 10^{-8} \mathrm{gm} \mathrm{NH}_{4}{ }^{+} \mathrm{g}^{-1}$ dry weight $\mathrm{h}^{-1}$, but were not consistently temperature dependent. Analysis of variance (Table $2 \mathrm{~b}$ ) shows that the effect of temperature was highly significant ( $F=32.935$; $\mathrm{p}=0.0001$ ). There seemed to be a general tendency for ammonia excretion rates to increase by approximately

Table 2. Neomysis integer. Synopses of analysis of variance for oxygen consumption, ammonia excretion and oxygen: nitrogen ratios for mysids chronically exposed to 'Sefir' oil WSF. Day and weight were treated as covariates

\begin{tabular}{|c|c|c|c|c|c|}
\hline Source & $\mathrm{df}$ & $\begin{array}{l}\text { Sum of } \\
\text { squares }\end{array}$ & $\begin{array}{c}\text { Mean } \\
\text { squares }\end{array}$ & F & $\mathrm{P}$ \\
\hline \multicolumn{6}{|c|}{ (a) Oxygen consumption } \\
\hline Weight & 1 & 1.567 & 1.567 & 6.048 & 0.015 \\
\hline Day & 1 & .094 & .094 & .363 & 0.548 \\
\hline Temperature & 3 & 22.992 & 7.664 & 22.431 & 0.001 \\
\hline Oil & 1 & .219 & 219 & .845 & 0.359 \\
\hline Temp X oil. & 3 & .281 & .094 & .361 & 0.781 \\
\hline Explained & 9 & 47.349 & 5.261 & 20.308 & 0.001 \\
\hline Residual & 155 & 40.155 & .259 & & \\
\hline Total & 164 & 87.504 & .534 & & \\
\hline \multicolumn{6}{|c|}{ (b) Ammonia excretion } \\
\hline Weight & 1 & 95.89 & 95.46 & 2.479 & 0.118 \\
\hline Day & 1 & 608.14 & 608.14 & 15.662 & 0.001 \\
\hline Temperature & 3 & 3836.39 & 1278.80 & 32.935 & 0.001 \\
\hline Oil & 1 & 39.23 & 39.22 & 1.010 & 0.316 \\
\hline Temp X oil & 3 & 211.25 & 70.42 & 1.814 & 0.147 \\
\hline Explained & 9 & 7316.59 & 812.95 & 20.937 & 0.001 \\
\hline Residual & 155 & 6018.34 & 38.83 & & \\
\hline Total & 164 & 13334.92 & 81.31 & & \\
\hline \multicolumn{6}{|c|}{ (c) Oxygen: nitrogen ratios } \\
\hline Weight & 1 & 5.10 & 5.100 & 0.354 & 0.553 \\
\hline Day & 1 & 225.03 & 225.038 & 15.636 & 0.001 \\
\hline Temperature & 3 & 182.09 & 60.70 & 4.217 & 0.007 \\
\hline Oil & 1 & 1.88 & 1.88 & 0.130 & 0.718 \\
\hline Temp X oil & 3 & 61.224 & 20.41 & 1.418 & 0.240 \\
\hline Explained & 9 & 581.81 & 64.65 & 4.492 & 0.001 \\
\hline Residual & 155 & 2230.77 & 14.39 & & \\
\hline Total & 164 & 2812.58 & 17.15 & & \\
\hline
\end{tabular}



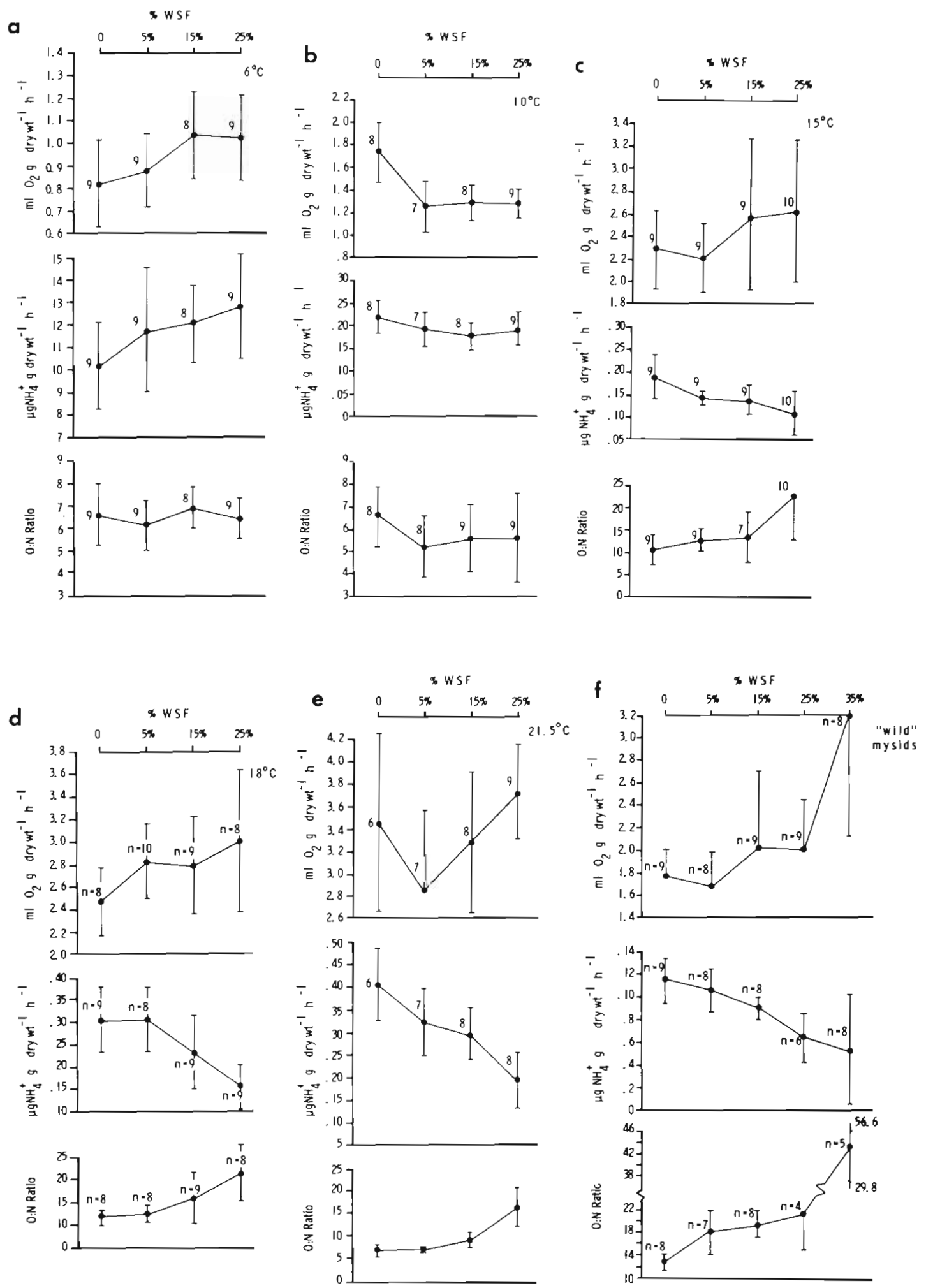

Fig. 4. Neomysis integer. Oxygen consumption, ammonia excretion, and oxygen : nitrogen ratios of adult mysids acclimated to test temperatures and exposed to high water-soluble fractions (WSF) during respirometry. (a) $6{ }^{\circ} \mathrm{C}_{i}$ (b) $10^{\circ} \mathrm{C}$; (c) $15^{\circ} \mathrm{C}_{i}(\mathrm{~d}) 18^{\circ} \mathrm{C} i$ (e) $21.5^{\circ} \mathrm{C}$; f) 'wild mysids' collected from the field $3 \mathrm{~h}$ before respirometry. Field and test temperatures were, respectively, 13.8 and $14.5^{\circ} \mathrm{C}$. Bars: 1 standard deviation of the mean in a to $e_{;}$in $f, 1$ standard error of the mean. Numbers by each point: number of replicates for each point 
10 to $20 \%$ during the 15 -d test period, based on comparisons between first and last day values. In the statistical analysis, the day is treated as a covariate, and is significant at the 0.001 level (Table $2 \mathrm{~b}$ ), indicating that the length of time under the test conditions had an effect on the ammonia excretion. However, oil did not affect ammonia excretion rates consistently during chronic exposure. This conclusion is borne out by the statistical analysis, where the oil exposure was not significant $(F=1.010 ; p=0.316)$. In addition, the interaction between temperature and oil was not significant ( $F=1.814 ; \mathrm{p}=0.147$; Table 3a).

$\mathrm{O}: \mathrm{N}$ ratios measured on the first day are comparatively low (Fig. 3), generally between 5 and 15, except for very high values of 17.5 and 22 for the $15^{\circ} \mathrm{C}$ control and oil, respectively. Several trends are apparent in the data. $\mathrm{O}: \mathrm{N}$ ratios tend to decrease as temperature increases. At all temperatures except $10^{\circ} \mathrm{C}$, the $\mathrm{O}: \mathrm{N}$ ratios increased on Day 5 but declined thereafter. At $15^{\circ} \mathrm{C}, \mathrm{O}: \mathrm{N}$ ratios declined throughout the test period, most markedly during the first $5 \mathrm{~d}$. Oil alone had no consistent effect on $\mathrm{O}: \mathrm{N}$ ratios throughout the test period. However, by the last day of the tests, control groups generally had higher $\mathrm{O}: \mathrm{N}$ ratios than the respective oil groups at all temperatures except $15^{\circ} \mathrm{C}$. Mean values were almost identical for the latter group.

For $\mathrm{O}: \mathrm{N}$ ratios, the day was the only statistically significant covariate, (Table $2 \mathrm{c} ; \mathrm{F}=15.636$; $\mathrm{p}=0.001$ ). Of the 2 factors, only temperature exerted a significant effect ( $F=4.217 ; \mathrm{p}=0.007$ ).

\section{Acute effects}

Temperature effects on oxygen consumption rates were virtually identical in the acute studies and the chronic ones (Fig. 4 a-e). The control oxygen consumption rates at 6 and $20^{\circ} \mathrm{C}$ were respectively 0.82 and $3.50 \mathrm{mg} \mathrm{O}_{2} \mathrm{~g}^{-1}$ dry weight $\mathrm{h}^{-1}$, over a 4 -fold increase. The effect of oil on oxygen consumption rates was significant both as a main effect $(F=4.172$; $p=.007)$, and in the interaction with temperature $(\mathrm{F}=2.682 ; \mathrm{p}=.003$, Table 3a).

The data were suitable for response surface analysis (Fig. 5). For this and subsequent regression analyses of acute responses, data were fitted by least squares to a model containing cubic, quadratic and linear terms for temperature and salinity and an interaction term for

Table 3. Neomysis integer. Analysis of variance for respiration rates, ammonia excretion rates, and oxygen-nitrogen ratios for mysids exposed under acute conditions to WSF of 'Sefier' oil. In all analyses weight is treated as a covariate

\begin{tabular}{|c|c|c|c|c|c|}
\hline Source & $\mathrm{df}$ & $\begin{array}{l}\text { Sum of } \\
\text { squares }\end{array}$ & $\begin{array}{c}\text { Mean } \\
\text { squares }\end{array}$ & $\mathrm{F}$ & $\mathrm{P}$ \\
\hline \multicolumn{6}{|c|}{ (a) Oxygen consumption rates } \\
\hline Weight & 1 & 3.443 & 3.443 & 22.141 & .0001 \\
\hline Temperature & 4 & 117.939 & 29.485 & 189.623 & .0001 \\
\hline Oil & 3 & 1.946 & .649 & 4.172 & .007 \\
\hline Temp X oil & 12 & 5.004 & 417 & 2.682 & .003 \\
\hline Explained & 20 & 136.218 & 6.881 & 43.802 & .0001 \\
\hline Residual & 143 & 22.235 & 0.155 & & \\
\hline Total & 163 & 158.453 & .972 & & \\
\hline \multicolumn{6}{|c|}{ (b) Ammonia excretion rates } \\
\hline Weight & 1 & 101.358 & 101.358 & 4.256 & .041 \\
\hline Temperature & 4 & 5588.027 & 1397.007 & 58.655 & .0001 \\
\hline Oil & 3 & 1671.747 & 557.249 & 23.397 & .0001 \\
\hline Temp X oil & 12 & 1659.293 & 138.247 & 5.806 & .001 \\
\hline Explained & 20 & 10401.777 & 520.089 & 21.836 & .0001 \\
\hline Residual & 143 & 3405.910 & 23.818 & & \\
\hline Total & 163 & 13807.688 & 84.710 & & \\
\hline \multicolumn{6}{|c|}{ (c) Oxygen: nitrogen ratios } \\
\hline Weight & 1 & 3.219 & 3.219 & 0.250 & .618 \\
\hline Temperature & 4 & 1476.825 & 436.706 & 33.850 & .0001 \\
\hline Oil & 3 & 951.396 & 317.132 & 24.582 & .0001 \\
\hline Temp X oil & 12 & 726.898 & 60.575 & 4.695 & .001 \\
\hline Explained & 20 & 3909.016 & 195.451 & 15.150 & .0001 \\
\hline Residual & 143 & 1844.875 & 12.901 & & \\
\hline Total & 163 & 5753.891 & 35.300 & & \\
\hline
\end{tabular}




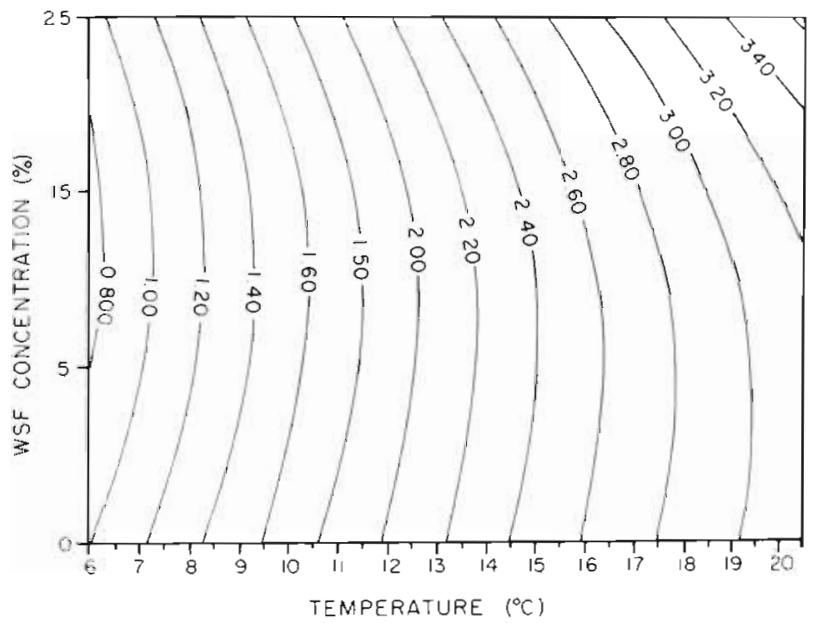

Fig. 5. Neomysis integer. Response surface diagram illustrating predicted oxygen consumption ( $\mathrm{ml} \mathrm{O}_{2} \mathrm{~g}^{-1}$ dry wt $\mathrm{h}^{-1}$ ) of adult mysids acclimated to temperatures between 6 and

$21.5^{\circ} \mathrm{C}$ and exposed to high WSF concentrations of light fuel oil

linear effects. The following model was plotted in Fig. 5:

$\mathrm{R}=0.6334+0.6202 \mathrm{~T}-0.004110 \mathrm{~T}^{3}-0.3287 \mathrm{D}+$ $0.01257 \mathrm{D}^{3}+.04647 \mathrm{TXD}$

$$
r=0.89
$$

where $\mathrm{R}=$ oxygen consumption; $\mathrm{T}=$ temperature; $\mathrm{D}=$ oil dose. This plot shows that the combined effects of both higher temperatures and higher oil levels were the ones producing the greatest effects while conversely, low temperatures seemed to confer the greatest resistance to petroleum hydrocarbons on the mysids.

Compared to oxygen uptake rates, ammonia excretion rates were much more reflective of oil exposure although temperature was also a significant factor (Fig. $3 \mathrm{a}-\mathrm{e}$ ). At all temperatures above $6{ }^{\circ} \mathrm{C}$, ammonia excretion declined with increasing oil dose. The extent of the decline was proportional to temperature with the greatest effect being observed at highest temperatures. It should be noted that when exposed to oil, different individual mysids exhibited ammonia excretion rates that could be grouped into 3 categories: (1) few individuals whose rates were very similar to the mean for the control group (i.e. unaffected); (2) the majority displayed excretion rates lower than the control; and (3) mysids whose ammonia excretion rates were so low that they could not be accurately determined. No control individuals ever displayed the third trait. Without any evidence to the contrary, one could assume that ammonia excretion was inhibited by high oil doses. At $6{ }^{\circ} \mathrm{C}$, the opposite trend was observed. Ammonia excretion increased with oil dose (Fig. 3a). Oil least affected ammonia excretion in $10^{\circ} \mathrm{C}$, indicating that this was close to the optimal level for this population of Neomysis integer. Analysis of variance for the ammonia excretion data indicates that all factors tested - temperature, oil and their interaction - are significant $(p<0.0001$; Table $3 b$ ). The regression equation contained the following terms:

$\mathrm{NH}_{4}{ }^{+}=-5.2703+17.9617 \mathrm{~T}-4.3773 \mathrm{~T}^{2}+$

$0.5723 \mathrm{~T}^{3}+$

$3.7702 \mathrm{D}-.04285 \mathrm{D}^{3}-1.8956 \mathrm{~T} \times \mathrm{D}$

$$
r=0.79
$$

where $\mathrm{NH}_{4}{ }^{+}=$ammonia excretion rate; $\mathrm{T}=$ temperature $;=$ oil dose. The response surface plotted from the model (Fig. 6) predicts a fairly broad range of factor combinations where ammonia excretion would be between 12 and $20 \times 10^{-8} \mathrm{~g} \mathrm{NH}_{4}^{+} \mathrm{g}^{-1}$ dry weight $\mathrm{h}^{-1}$ with higher temperatures in particular associated with marked increases.

At temperatures above $10^{\circ} \mathrm{C}$ (i.e. those where oxygen consumption increased while ammonia excretion decreased) the $\mathrm{O}: \mathrm{N}$ ratios increased, often drastically. Analysis of variance for these data indicates that as a covariate, weight was not significant $(F=0.250$; $p=0.618$; Table $3 c$ ), in contrast to the observations of the effect of weight on metabolic rate functions. However, both main effects, temperature and salinity, and their interaction, are significant ( $p<0.0001$ ).

The regression equation used to plot the response surface diagram in Fig. 7 is:

$$
\begin{aligned}
& O: N=13.5215-6.4842 \mathrm{~T}+3.2676 \mathrm{~T}^{2}-0.4817 \mathrm{~T}^{3}- \\
& 4.1301 \mathrm{D}+0.1486 \mathrm{D}^{3}+1.0347 \mathrm{TXD} \quad
\end{aligned}
$$

where $\mathrm{O}: \mathrm{N}=$ oxygen: nitrogen ratio; $\mathrm{T}=$ temperature; $\mathrm{D}=$ dose of oil. The response surface diagram

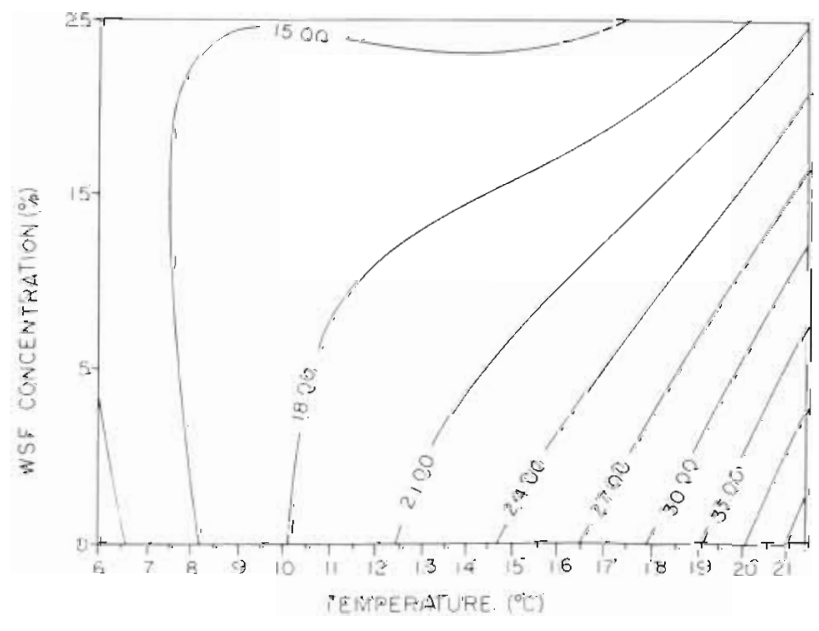

Fig. 6. Neomysis integer. Response surface diagram illustrating predicted ammonia excretion $\left(\mu \mathrm{g} \mathrm{NH}_{4}{ }^{+} \mathrm{g}^{-1}\right.$ dry wt $\mathrm{h}^{-1} \mathrm{x}$ 100) of adult mysids acclimated to temperatures between 6 and $21.5^{\circ} \mathrm{C}$ and exposed to high WSF concentrations of light fuel oil 
illustrates the prediction that $O: N$ ratios for this species tend to be relatively low (i.e. less than 12 under most factor combinations) and rise with both temperature, and especially oil exposure. All of the experiments discussed above were performed with mysids acclimated to laboratory conditions for varying periods of time. These conditions might be suspected to cause or to facilitate responses atypical of field populations. Therefore, we performed a corollary experiment using field-collected mysids. Two observations are salient in comparisons with the $15^{\circ} \mathrm{C}$ laboratory acclimated mysids, and these field-collected ones, tested at $14.8^{\circ} \mathrm{C}$, the seasonal ambient (Fig. $3 \mathrm{f}$ ). The overall trends are similar in that oxygen consumption increased and ammonia excretion decreased with increasing oil dose. However, the magnitude of the responses were less, ca. $25 \%$ (oxygen consumption) and ca. $33 \%$ (ammonia excretion) for field-collected mysids compared to laboratory acclimated animals. The $\mathrm{O}: \mathrm{N}$ ratios of field-collected mysids also tend to be slightly higher than those of laboratory individuals. One-way analysis of variance for data of field collected mysids indicates that for both oxygen consumption and $\mathrm{O}: \mathrm{N}$ ratios, oil exposure produced a significant effect (Table 4). The data for the nitrogen excretion were highly variable, and no factor tested satisfactorily explains the observed variance. This wide variation may be attributed to dietary composition and feeding frequency of wild populations. Despite the variability, the trends in the data remain convincing when considered along with the response of laboratory-reared mysids.

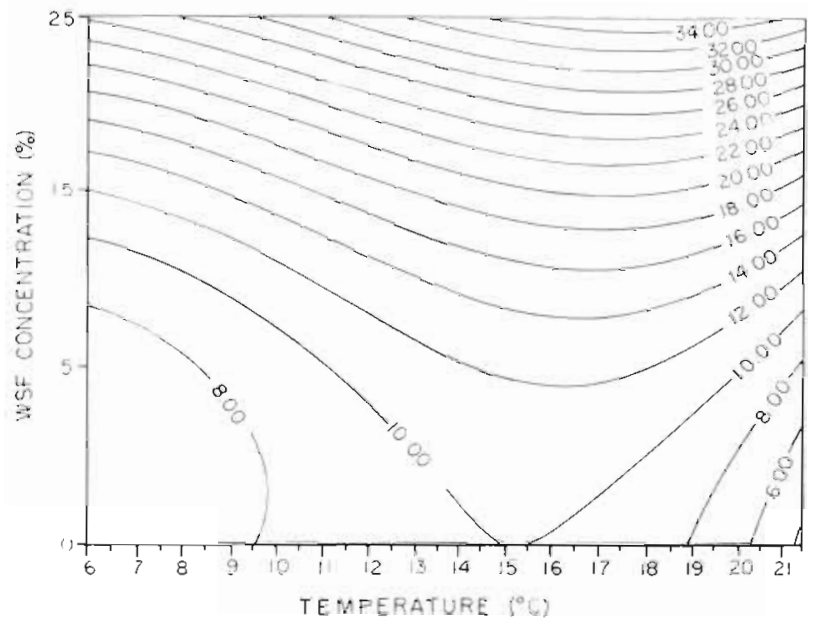

Fig. 7. Neomysis integer. Response surface diagram illustrating predicted oxygen: nitrogen ratios of adult mysids acclimated to temperatures between 6 and $21.5^{\circ} \mathrm{C}$ and exposed to high WSF concentrations of light fuel oil

\section{DISCUSSION}

When the 'Sefir' sank, recommendations for amelioration were based on comparisons with the effects of the Buzzard's Bay (Massachusetts, USA) spill where a similar fuel oil was released (Sanders et al., 1980). Field observations made on Oland (Sweden) showed large mortalities of littoral fauna, including mysids (Lindén et al., 1983). Subsequently, much of the oil was eventually removed but its chronic effects still

Table 4. Neomysis integer. Analysis of variance of data for oxygen consumption, ammonia excretion and oxygen: nitrogen ratios of field-collected mysids, exposed to WSF of 'Sefir' oil. In all analyses weight is treated as a covariate

\begin{tabular}{|c|c|c|c|c|c|}
\hline Source & $\mathrm{df}$ & $\begin{array}{l}\text { Sum of } \\
\text { squares }\end{array}$ & $\begin{array}{c}\text { Mean } \\
\text { squares }\end{array}$ & $\mathrm{F}$ & $P$ \\
\hline \multicolumn{6}{|c|}{ (a) Oxygen consumption } \\
\hline Weight & 1 & 4.332 & 4.332 & 21.466 & 0.0001 \\
\hline Oil & 4 & 4.200 & 1.050 & 5.203 & 0.003 \\
\hline Explained & 5 & 8.532 & 1.706 & 8.456 & 0.0001 \\
\hline Residual & 28 & 5.651 & 0.202 & & \\
\hline Total & 33 & 14.183 & 0.430 & & \\
\hline \multicolumn{6}{|c|}{ (b) Ammonia excretion } \\
\hline Weight & 1 & 0.035 & 0.035 & .001 & 0.970 \\
\hline Oil & 4 & 130.595 & 32.649 & 1.358 & 0.274 \\
\hline Explained & 5 & 130.630 & 26.126 & 1.086 & 0.389 \\
\hline Residual & 28 & 673.334 & 24.048 & & \\
\hline Total & 33 & 803.964 & 24.363 & & \\
\hline \multicolumn{6}{|c|}{ (c) Oxygen: nitrogen ratios } \\
\hline Weight & 1 & 1065.3 & 1665.3 & 9.126 & 0.005 \\
\hline Oil & 4 & 1883.5 & 470.9 & 2.580 & 0.059 \\
\hline Explained & 5 & 3548.8 & 709.8 & 3.890 & 0.008 \\
\hline Residual & 28 & 5109.4 & 182.5 & & \\
\hline Total & 33 & 8658.2 & 262.4 & & \\
\hline
\end{tabular}


remained a concern. The studies discussed here were initiated in an attempt to extend the scope of previous laboratory studies on the acute and sublethal effects of oil to a characteristic organism of the Baltic Sea, a cold, low-salinity habitat. Thus, while a particular event motivated these studies, generalizations may be applicable to other organisms and pollution events.

As a marine ecosystem, the Baltic Sea is remarkable for its large seasonal temperature range (Segerstråle, 1971). Temperature was the single factor exerting the strongest effect on the physiological processes studied here. At temperatures between 6 and $15^{\circ} \mathrm{C}$, oxygen consumption $Q_{10}$ values were usually less than 2 , but above 2 for the temperature interval between 15 and $20^{\circ} \mathrm{C}$. These values are typical for a variety of mysids from similar habitats: Mysis relicta (Lasenby and Langford, 1973), and Neomysis americana (Clutter and Theilacker, 1971). Chin (1971), in a study of respiratory rates of $N$. awatschensis acclimated to temperatures of 5 to $26{ }^{\circ} \mathrm{C}$ in $5 \mathrm{C}^{\circ}$ intervals, measured highest but most variable $Q_{10}$ in the temperature interval from 15 to $25^{\circ} \mathrm{C}$; similar qualitatively to the observations we have made with $N$. integer.

The response of ammonia excretion rates to different temperatures is qualitatively similar to but quantitatively less marked than that of oxygen consumption. Compared to oxygen consumption rates, ammonia excretion rates exhibited far less temperature compensation. Lack of temperature compensation in ammonia excretion also has been observed in Mytilus edulis (Bayne and Scullard, 1977). The values for ammonia excretion in Neomysis integer and the effect of temperature are remarkably similar for Paracanthomysis hispida (Lee and Chin, 1976).

The regression analysis performed for the acute responses to oil exposure showed that for both, oxygen consumption and ammonia excretion, significant nonlinear effects could be attributed to temperature. Linear terms were strongly positively correlated with temperature. Similar generalizations about quadratic and cubic effects in the models tested cannot be made; both vary depending on the response measured. To our knowledge, nonlinear effects have been considered in only one other study. Simmons and Knight (1975) considered the effect of temperature, salinity, size, sex and season on respiration rate of the mysid Neomysis mercedis (= intermedia and awatschensis). While the statistical models they tested were different from ours, they also found significant positive correlations with temperature and nonlinear temperature effects.

The extent to which laboratory acclimation influenced physiological parameters can be seen by comparing the values of field-collected with those of the laboratory-acclimated mysids, and by noting the changes with time during the chronic exposure pro- tocol. During the chronic exposure studies at $20^{\circ} \mathrm{C}$, respiration rates rose from Days 1 to 10 before appearing to stabilize. This increase probably reflects stress caused by increased temperatures.

It should be noted that most mysids died after about $2.5 \mathrm{wk}$ exposure to $20^{\circ} \mathrm{C}$. Mortality was usually precipitous with almost all mysids succumbing within a 3d period. Although no data specifically examining the subject are known to us, the population of mysids we studied probably rarely experiences temperatures above $15^{\circ} \mathrm{C}$, and never for periods exceeding a few days at a time. Thus, the response under this highest temperature regime is probably a resistance adaptation (Precht, 1958; Vemberg and Vernberg, 1972) and is not precisely comparable to the ones at lower temperatures.

Ammonia excretion was similarly affected by laboratory acclimation. The slow rise during the $15 \mathrm{~d}$ of the tests at all 4 temperatures was statistically significant (Table $2 \mathrm{~b}$ ). This probably can be attributed to the feeding regime. Not only was food in excess, but the commercial food (Tetramin ${ }^{(R)}$ ) was particularly rich in nitrogen. Both the type and availability of food are known to influence ammonia excretion (Conover and Corner, 1968; Corner and Cowey, 1968; Capuzzo and Lancaster, 1979; Bayne and Scullard, 1977).

The 'Sefir' oil tested here contained a prominent mono- and diaromatic water-soluble fraction, to which the toxic action of oil is generally attributed (Anderson, et al., 1974a, b; Pulich et al., 1975; Anderson, 1977; Lee and Nicol, 1977). Dicyclic hydrocarbons are thought to be particularly hazardous since they are relatively water soluble, but rapidly partition from the water phase into the lipids of organisms. It is in the lipid portion of membranes where the most significant interactions occur, especially for the aromatics, which interact primarily with the membranes' surface (Roubal, 1974; Roubal and Collier, 1975). Disruption of transport functions especially in gills or nervous tissue would be the most obvious physiological effect.

The effect of oil on various physiological functions is thought to be concentration dependent. (Edwards, 1978; Laughlin and Neff, 1981). In low concentrations, oil exerts its effect predominantly through its action as a narcotic (Crisp et al., 1967). Changes in oxygen uptake under these conditions are primarily secondary effects of decreased activity of affected animals.

Higher oil doses would initiate effects on membrane-mediated responses. The respiration of mitochondria isolated from oil exposed amphipods (Onisimus affinis) exhibited higher respiration rates than the controls not exposed to petroleum hydrocarbons (Percy, 1977). These changes were presumably an enhancement of some aspect of electron transport produced through effects on mitochondrial membranes. 
The marked increase in oxygen consumption of mysids acutely exposed to oil in the higher temperatures is perhaps produced by a similar process.

Changes in ammonia excretion probably are produced by a similar role of hydrocarbon impingement on membrane function. Our argument is based on 2 facts. First, $\mathrm{NH}_{4}{ }^{+}$, the predominant chemical species at in vivo $\mathrm{pH}$, is actively transported from crustaceans (Kormanic and Cameron, 1981). In addition, Towle et al. (1976), Towle and Taylor (1976), Mangum and Towle (1977) and Mangum et al. (1978), demonstrated that decapod crustaceans (the blue crab Callinectes sapidus), molluscs, and annelids excreted ammonium even with an excess in the medium. The plausibility of an effect of oil on ammonia exchange is strengthened by the observation that petroleum hydrocarbons tend to accumulate initially to high concentrations in the gills of several species of marine organisms (Anderson, 1974b; Neff et al., 1976). We suggest that the decline in ammonia excretion rates observed under several conditions of acute oil exposure was caused by an effect on $\mathrm{NH}_{4}{ }^{+}$transport functions of the gill membranes. Second, effects on intermediary metabolism can be ruled out because previous investigations have shown that oil does not affect any enzyme systems responsible for ammonia production (Heitz et al, 1974).

The study most similar in scope and design to the present one is that of Capuzzo and Lancaster (1981). They determined respiration rates, ammonia excretion, and $\mathrm{O}: \mathrm{N}$ ratios of different larval stages of lobsters Homarus americanus, exposed for up to $5 \mathrm{~d}$ to $1.25 \mathrm{ppm}$ total hydrocarbons of Southern Louisiana Crude Oil. They found that Stage I larvae exposed for $24 \mathrm{~h}$, and all stages exposed for $72 \mathrm{~h}$, exhibited significant reductions in respiration rates. Ammonia excretion was significantly higher after $72 \mathrm{~h}$ exposure to oil for Stages II and III. These physiological changes were also accompanied by significant decreases in protein-lipid ratios of oil-exposed larvae. During our chronic study with mysids, we did not observe such marked changes in physiological parameters as those reported by Capuzzo and Lancaster (1981), probably because our hydrocarbon concentrations were much lower. To our knowledge, no one has investigated the interaction of physical factors and oil on these physiological mechanisms. With respect to Neomysis, it appears that at temperatures between 15 and $20{ }^{\circ} \mathrm{C}$, under conditions of resistance adaptation, temperature alone exerts a main effect and the chronic effect of hydrocarbons is not measurable. On the other hand, at temperatures below $10^{\circ} \mathrm{C}$, the hydrocarbons do qualitatively affect mysids and lobster larvae alike through impingements upon various components of the energy budget. Quantitative differences are probably due to differences in types and concentrations of the hy- drocarbons present in the WSF of each oil, species differences, and those applicable to larval (lobsters) and adult (mysid) crustaceans.

The concentration of petroleum hydrocarbons used in the acute studies probably would occur where oil is escaping from a sunken ship or in the vicinity of a spill, especially one in enclosed or shallow water. The major pollution problem with oil is thought to be chronic, low-level inputs (NAS, 1975; Gosselink, 1976; Neff, 1979) causing sublethal responses. One such response that has received some attention has been that of energy budgets. Gilfillan (1975) and Gilfillan et al. (1976) demonstrated that bivalves from an oil-polluted habitat exhibited higher respiration rates and lower carbon assimilation values than controls from nonpolluted areas. Because of methodological difficulties, studies with crustaceans have been more limited in scope. Nevertheless, several have demonstrated changes in respiration, growth and other components of the energy budget (Edwards, 1978; Johns and Pechenik, 1980; Laughlin and Neff, 1977, 1980, 1981; Capuzzo and Lancaster, 1981). The data for Neomysis suggest that such changes also occur in this species, but are influenced by interactions between hydrocarbon concentration and the prevailing physical factor regime.

Acknowledgements. This work was supported by a visiting research fellowship from the Swedish Environmental Research Institute (IVL) to R. L. Manuscript preparation costs were born by the US Office of Naval Research. We thank K. Norlund for her unstinting technical assistance. Discussions with A. Johansson and B.-E. Bengtsson regarding, respectively, the obtaining and laboratory maintenance of mysids were most helpful. K.-J. Lehtinen constructed the oil-dosing apparatus. C. Lehtinen made many of the sample collections for hydrocarbon analyses and determinations were made by the Analysical Chemistry Laboratory, IVL, Stockholm.

\section{LITERATURE CITED}

American Petroleum Institute (1958). Determination of volatile and non-volatile oily material. Infrared spectrophotometric method. No. 733-48, American Petroleum Institute, Washington, D.C.

Anderson, J. W. (1977). Responses to sublethal levels of petroleum hydrocarbons: are they sensitive indicators and do they correlate with tissue contamination. In: Wolfe, D. A. (ed.) Fate and effects of petroleum hydrocarbons in marine organisms and ecosystems. Pergamon Press, New York, p. 95-114

Anderson, J. W., Neff, J. M. Cox, B. A., Tatem, H. E., Hightower, G. M. (1974a). Characteristics of dispersions and water-soluble extracts of crude and refined oils and their toxicity to estuarine crustaceans and fish. Mar. Biol. 27: 75-88

Anderson, J. W., Neff, J, M., Cox, B. A., Tatem, H. E., Hightower, G. M. (1974b). The effects of oil on estuarine animals: toxicity, uptake and depuration, respiration. In: Vernberg, F. J., Vernberg, W. B. (eds.) Pollution and phy- 
siology of marine organisms. Academic Press, New York, p. $285-310$

Bayne, B. L., Scullard, C. (1977). Rates of nitrogen excretion by species of Mytilus (Bivalvia: Mollusca). J. mar. biol. Ass. U.K. 57 : 355-369

Capuzzo, J. M., Lancaster, B. A. (1979a). Some physiological and biochemical considerations of larval development in the American lobster, Homarus americanus Milne Edwards. J. exp. mar. Biol. Ecol. 40: 53-62

Capuzzo, J. M., Lancaster, B. A. (1979b). Larval development in the American lobster, Homarus americanus Milne Edwards: changes in metabolic activity and $O: N$ ratio. Can. J. Zool. 57: 1845-1848

Capuzzo, J. M., Lancaster, B. A. (1981). Physiological effects of South Louisiana crude oil on larvae of the American lobster (Homarus americanus). In: Vernberg, F. J., Calabrese, A., Thurberg, F. P., Vernberg, W. B. (eds.) Biological monitoring of marine pollutants. Academic Press, New York, p. 405-523

Chin, P. (1971). The effect of temperature on respiratory metabolism of the mysid Neomysis awatschensis (Brandt). Pubiications of the Marine Laboratory of Pusan Fisheries College 4: 9-18

Clutter, R. I., Theilacker, G. H. (1971). Ecological efficiency of a pelagic mysid shrimp: estimates from growth, energy budget and mortality studies. Fish. Bull., NOAA 69: 93-115

Conover, R. J., Corner, E. D. S. (1968). Respiration and nitrogen excretion by some marine zooplankton in relation to their life cycles. J. mar. biol. Ass. U.K. 48: 49-75

Corner, E. D. S., Cowey, C. B. (1968). Biochemical studies on the production of marine zooplankton. Biol. Rev. 43: 393-426

Crisp, D. J., Christie, A. O., Gholashy, A. F. A. (1967). Narcotic and toxic action of organic compounds on barnacle larvae Comp. Biochem. Physiol. 22; 129-149

Edwards, R. R. C. (1978). Effects of water-soluble oil fractions on metabolism, growth and carbon budget of the shrimp Crangon crangon. Mar. Biol. 46: 259--265

Gilfillan, E. S. (1975). Decrease of net carbon flux in two species of mussels caused by extracts of crude oil. Mar. Biol. 29: 53-57

Gilfillan, E. S., Mayo, D., Hanson, S., Donovan, D., Jiang, L. C. (1976). Reduction in carbon flux in Mya arenaria caused by a spill of No. 6 fuel oil. Mar. Biol. 37: 115-123

Grossling, B. F. (1976). An estimate of the amounts of oil entering the oceans. In: Sources, effects and sinks of hydrocarbons in the aquatic environment. American Institute of Biological Sciences, Washington, D. C., p. 5-36

Heitz, J. R., Lewis, L., Chambers, J., Yarbrought, J. D. (1974). The acute effects of Empire Mix crude oil on enzymes in oysters, shrimp and mullet. In: Vernberg, F. J., Vernberg, W. B. (eds.) Pollution and physiology of marine organisms. Academic Press New York, p. 311-328

Hemmingsen, A. M. (1960). Energy metabolism as related to body size and respiratory surfaces, and its evolution. Rep. Steno. Mem. Hosp. Nordisk Insulin Lab. 9: 1-110

Johns, D. M., Pechenik, J. A. (1980). Influence of the wateraccommodated fraction of No. 2 fuel oil on energetics of Cancer irroratus larvae. Mar. Biol. 55: 247-254

Kormanic, G. A., Cameron, J. N. (1981). Ammonia excretion in animals that breathe water: a review. Mar. Biol. Lett. 2: $11-23$

Lasenby, D. C., Langford, R. R. (1973). Feeding and assimilation of Mysis relicta. Limnol. Oceanogr. 18: 280-285

Laughlin, R. B., Jr., Neff, J. M. (1977). Interactive effects of temperature, salinity shock and chronic exposure to No. 2 fuel oil on survival, development rate and respiration of the horseshoe crab, Limulus polyphemus. In: Wolfe, D. A. (ed.) Fate and effects of petroleum hydrocarbons in marine organisms and ecosystems. Pergamon Press, New York, p. 182-191

Laughlin, R. B., Jr., Neff, J. M. (1980). The respiratory response of larval mud crabs, Rhithropanopeus harrisii, following exposure to factorial combinations of temperature, salinity and phenanthrene (a petroleum-derived polynuclear aromatic hydrocarbon). Estuar. coast. mar. Sci. 10: 655-669

Laughlin, R. B., Jr., Neff, J. M. (1981). Ontogeny of respiratory and growth responses of larval mud crabs, Rhithropanopeus harrisii exposed to different temperatures, salinities and naphthalene concentrations. Mar. Ecol. Prog. Ser. 5: 319-332

Laughlin, R. B., Jr., Wofford, H. W., Neff, J. M. (1979). A simple potentiometric method for the rapid determination of respiration rates of small aquatic organisms. Aquaculture 16: 77-82

Lee, C. Y., Chin, P. (1976). Effects of temperature and starvation on the oxygen consumption and nitrogen excretion of a mysid Paracanthonysis hispida. Publs Inst. mar. Sci. natl. Fish. Univ. Pusan, Korea 9: 25-31

Lee, W. Y, Nicol, J. A. C. (1977). The effects of the water soluble fractions of No. 2 fuel oil on the survival and behavior of coastal and oceanic zooplankton. Environ. Pollut. 12: 279-292

Lindén, O., Mattsson, J., Notini, M. (1983). A spill of light fuel oil in the Baltic Sea. In 1983 Oil Spill Conference. American Petroleum Institute, Washington, D. C., p. 517-520

Mangum, C., Towle, D. (1977). Physiological adaptation to unstable environments. Am. Sci. 65: 67-75

Mangum, C. P., Dykens, J. A., Henry, R. P., Polites, G. (1978). The excretion of $\mathrm{NH}_{4}{ }^{+}$and its ouabain sensitivity in aquatic annelids and molluscs. J. exp. Zool. 203: 151-157

National Academy of Sciences (1975). Petroleum in the marine environment. Report from the workshop on inputs, fates and effects of petroleum in the marine environment. Ocean Affairs Board, Washington, D. C., p. 1-107

Neff, J. M. (1979). Polycyclic aromatic hydrocarbons in the aquatic environment: sources, fates and biological effects. Applied Science Publ., London

Neff, J. M., Anderson, J W (1975). An ultraviolet spectrophotometric method for the determination of naphthalenes and alkylnaphthalenes in the tissues of oil contaminated marine animals. Bull. Env. Contam. Tox. 14: $122-128$

Nie, N. H., Hull, C. H., Jenkins, J. G., Steinbrenner, K., Bent, D. H. (1975). Statistical package for the social sciences. McGraw-Hill, New York

Percy, J. A. (1977). Effects of dispersed crude oil upon the respiratory metabolism of an arctic marine amphipod, Onisimus (Bolkisimus) affinis. In: Wolfe, D. A. (ed.) Fate and effects of petroleum hydrocarbons in marine organisms and ecosystems. Pergamon Press, New York, p. $192-200$

Precht, $H$. (1958). Concepts of the temperature adaptation of unchanging reaction systems of cold-blooded animaIs. In: Prosser, C. L. (ed.) Physiological adaptation. American Physiological Society, Washington, D.C., p. 167-180

Pulich, W M., Jr., Winters, K., Van Baalin, C. (1975). The eftects of a No. 2 fuel oil and two crude oils on the growth and photosynthesis of microalgae. Mar Biol 28: 87-94

Roubal, W T. (1974). Spin-labeling of living tissue - a method for investigating pollutant-host interaction. In: Vernberg, 
F. J., Vernberg, W. B. (eds.) Pollution and physiology of marine organisms. Academic Press, New York, p. 367-380

Roubal, W. T., Collier, T. K. (1975). Spin-labeling techniques for studying mode of action of petroleum hydrocarbons on marine organisms. Fish. Bull. U.S. 73: 299-305

Rudling, L. (1976). Oil pollution in the Baltic Sea. A chemical analytical search for monitoring methods. Statens Naturvårdsverk, Publication No. PM 783

Sanders, H. L., Sanders, J., Grassle, J. F., Hampson, G. R., Morse, L. S., Gamer-Price, S., Jones, C. C. (1980). Anatomy of an oil spill: long-term effects from the grounding of the barge 'Florida' off West Falmouth, Massachusetts. J. mar. Res. 38: 265-380

Segerstrăle, S. B. (1971). Aspects of the biology of the Baltic Sea with special reference to the littoral zone. In: Riser, $N$. W., Carlson, A. G. (eds.) Proceedings of the symposium on cold water inshore marine biology. Northeastern University, Boston, p. 7-13

Simmons, M. A., Knight, A. W. (1975). Respiratory response of
Neomysis intermedia (Crustacea: Mysidacea) to changes in temperature, salinity and season. Comp. Biochem. Physiol. 50A: 181-193

Solorzano, L. (1969). Determination of ammonia in natural waters by the phenol-hypochlorite method. Limnol. Oceanogr. 14: 799-801

Sprague, J. B. (1969). Measurement of pollutant toxicity to fish. I. Bioassay methods for acute toxicity. Wat. Res. 3 : $793-821$

Towle, D. D., Taylor, D. D. (1976). Effect of $\mathrm{NH}_{4}^{+}$and $\mathrm{K}^{+}$on $\mathrm{Na}^{+}$-transport. ATPase activity of blue crab gill. Am. Zool. 16: 224 (Abstract)

Towle, D. W., Palmer, G. E., Harris, J. L. (1976). Role of gill $\mathrm{Na}^{+}+\mathrm{K}^{+}$dependent ATPase in acclimation of blue crabs (Callinectes sapidus) to low salinity. J. exp. Zool. 196: $315-321$

Vernberg, W., Vernberg, J. F. (1972). Environmental physiology of marine organisms. Springer-Verlag, New York

This paper was presented by Dr. D. Alderdice; it was accepted for printing on February 5, 1983 